\title{
Does Three Strikes Really Deter? A Statistical Analysis Of Its Impact On Crime Rates In California'
}

John Kelly, Philadelphia University, USA

Anusua Datta, Philadelphia University, USA

\begin{abstract}
This study uses California crime statistics for the years 1984-2004, to determine what effect, if any, the increased sentencing standards under the three-strikes legislation in California have had in deterring crime. This study follows a new approach in differentiating between the incapacitation effect and the deterrent effect of the law. Incapacitation is tested by tracking the change in prison population. Our results show that the three strikes legislation had a significant deterrent effect on total and property crime, but not so for violent crime. We find no support for incapacitation in the limited time period following the three-strikes legislation.
\end{abstract}

Keywords: Three Strikes, deterrence, incapacitation

\section{INTRODUCTION}

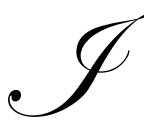
$\mathrm{n}$ response to what had been a rapid increase in crime in the preceding decade, the citizens of California voted in favor of a bill proposing a three strikes law in November 1994. This law provided for lengthened prison sentences for repeat offenders. The letter of the law states that offenders who commit one violent or serious felony offense are subject to harsher sentences for any subsequent crime. In the case of a second violent or serious offense, the offender would receive a sentence length double what the typically suggested sentence would be. Additionally, property crimes, specifically theft, become felony offenses in the event that an individual has a prior conviction of the same nature. For example, suppose an individual is convicted of two counts of auto theft once and is then arrested for grand theft a decade after his release from prison. The charge, which can be considered a misdemeanor and which carries a one year sentence, is elevated to felony status and the offender would be sentenced to 2 years imprisonment. Additionally, the offender must serve a minimum of $80 \%$ of the sentence before having the chance of parole.

Any offender who is arrested and charged with a violent or serious felony offense that has two or more of the same convictions can be and typically is sentenced to a minimum of 25 years and a maximum of life in prison in California's judicial system, given the specific nature of their offenses. The basic sentencing structure is: first offense: standard, second offense: double suggested sentence, third offense: 25 to life. The rationale behind the law was that extended sentences would remove repeat offenders from society for long periods of time, thereby restricting their ability to commit additional crimes. Further, the threat of long sentences would also deter would-be offenders from committing new crimes.

\footnotetext{
${ }^{1}$ An earlier version of this paper was presented by John Kelly, at the Undergraduate Business and Economics Conference, at Ursinus College on April 2008. We wish to extend our thanks to an anonymous referee for valuable suggestions on an earlier version.
} 


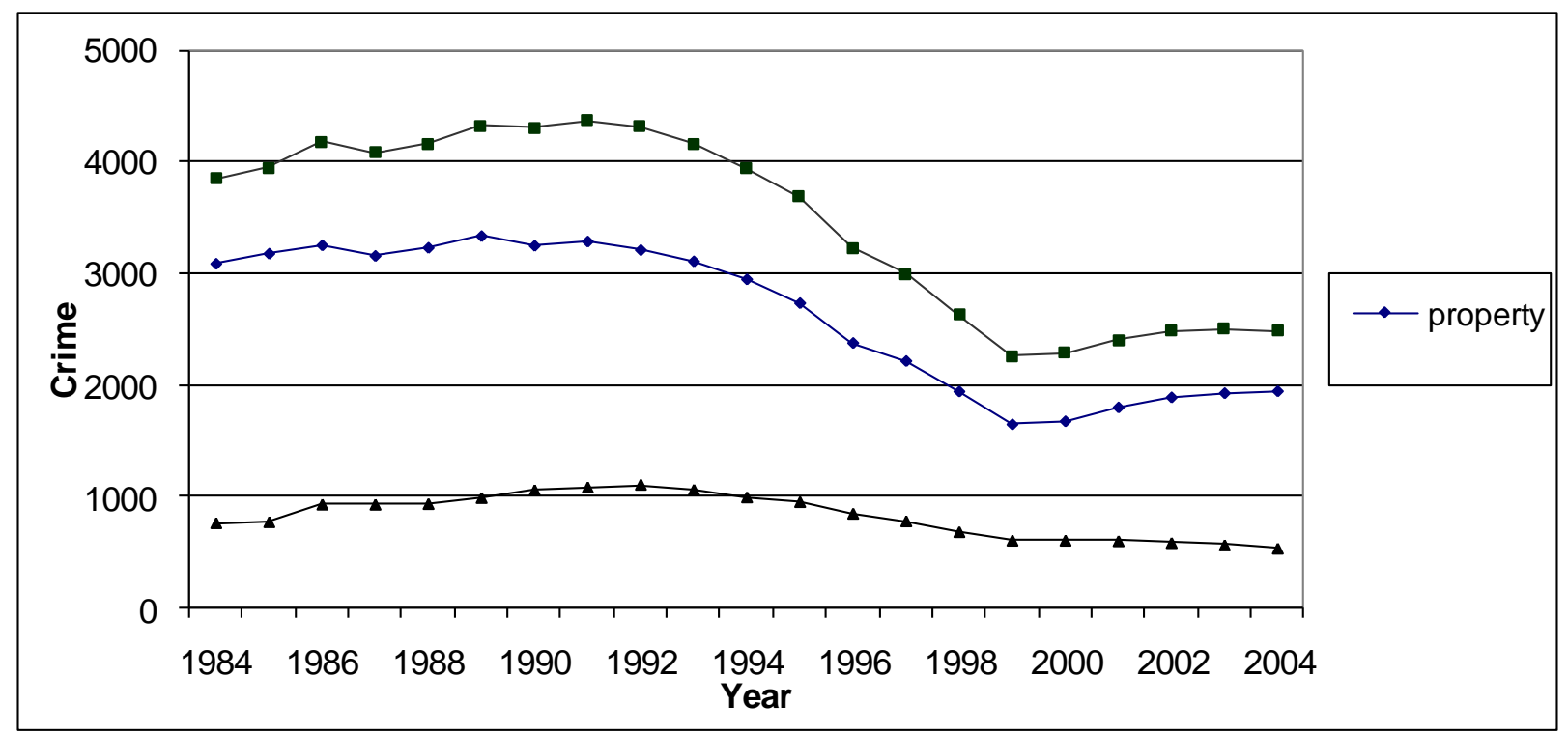

Figure 1. Crime in California per 100,000 population: 1984-2004

Figure 1, shows significant declines in property and total crime from 1992 onwards. Although violent crime also declined during the period, the decline is not as steep. Many supporters point to the three strikes law as the most prominent reason for the notable and consistent drop in crime in the period following the law's passage. Detractors on the other hand point to the fact that crime was already going down before its passage. Critics also point out that most crimes are committed when criminals are young, locking felons away for long periods, does not serve any useful purpose. Since its implementation, convicts and their families have appealed, citing cruel and unusual punishment.

While there have been many studies ${ }^{2}$ on the effect of the three-strikes legislation, serious statistical analysis of the issue include studies by Zimmring et al. 2001 and Marvell and Moody, 2001, followed by Shepherd (2002), Helland and Taborrak (2002) and Worrall (2004). The evidence from these studies are somewhat mixed. While Shepherd finds that the three-strikes legislation has a significant deterrent effect, studies by Zimmring (2001) and Worrall (2004) do not find evidence of deterrence, rather that crime is reduced due to incapacitation. Still others like Marvell and Moody (2001) find that the laws caused violent crime to increase.

The present study explores the deterrent and incapacitative effects of the three-strikes legislation in California by providing a more definitive test for incapacitation than the ones devised by Marvell and Moody (2001) and used by Worrall (2004).

\section{PREVIOUS RESEARCH}

Becker's (1968) seminal research on an economic model of crime effectively changed the way that analysts look at deterrence. Becker wrote that criminals act based upon three criteria: the benefit of a given crime - both financial and psychological, the legitimate opportunities an individual has to generate those same benefits and the likelihood of being apprehended and sentenced. If the potential costs of committing crime are greater than the benefits, an individual is deterred from making a criminal decision. Many of these ideas are borrowed directly by Kessler and Levitt (1999) and Shepherd (2002), as seen below.

\footnotetext{
${ }^{2}$ See e.g. studies by Macallair and Males (1999) California's Center of Juvenile and Criminal Justice and Brown and Jolivette (2005)
} 
Kessler and Levitt (1999) use a theoretical model to show how sentence enhancements (under Proposition 8) can be used to distinguish between the incapacitation and deterrent effect of the legislation. Proposition 8 , the first sentence enhancement legislation similar to the three-strikes law was passed in 1982 in California. The authors argue that, since enhancements are tacked on to prison sentences that would have been served anyway, there is no immediate incapacitation effect. Thus any decline in crime immediately following such legislation can be attributed to deterrence. Further, they also argue that if incapacitation is the driving force, then the three strikes law (under Proposition 8) should lead to sizeable increases in the number of felons behind bars and eventually to a prison population that is aged out of crime. On the other hand if three strikes leads to deterrence, it should result in a decline in crime along with a decline in incarceration. Their results provide mixed support for the three strikes law. Using data on eligible and ineligible crimes they find that Proposition 8 reduced eligible crimes by 4 percent within a year and 8 percent 3 years hence. They also found large lagged declines in crime, consistent with incapacitation.

Shepherd (2002) published a study attempting to address the problems facing three prominent studies (Kessler and Morrison, 1998, Marvell and Moody, 2001 and Zimmring et al. 2001) regarding the deterrent effect of California's three-strikes law. The Zimmring (2001) study drew its conclusions from raw data before and after the passage of the law, while Kessler and Morrison (1998) and Marvell and Moody (2001) used a dummy variable to represent the existence of a strike law in states. These studies either found no deterrent effect for the three-strikes law or that it actually increased crime. Shepherd (2002) argues that a dummy variable measure of three-strikes, does not account for how frequently or aggressively states apply the three-strikes law and therefore does not fully capture the deterrent effect. Further, that aggregate data at the state level overlooks county-specific variations.

Instead, Shepherd uses the probability of a three-strikes sentence, calculated by dividing the number of three-strikes sentences by the number of individuals receiving any sentence, to measure deterrence. Using data at the county-level, the study found that the three-strikes legislation had resulted in significant reductions in crime throughout the state of California.

Helland and Tabarrok (2002), analyzed the findings and methods of Kessler and Levitt (1999) and Shepherd (2002) and developed a non-parametric approach to analyze the effect of pre-and post legislation on aggregate crime. This study followed the survival rates of a set of recent prison releases to calculate the likelihood of relapse and subsequent re-incarceration. Focusing on criminal behavior allowed Helland and Tabarrok to directly evaluate criminal decision making and its relation to legislative deterrence; his study found a pronounced deterrent effect (Helland and Tabarrok, 2002).

Thompson (2002) reminds us, in a socio-legal perspective, that criminals are highly unlikely to weigh the cost/benefit ratio discussed by Becker when committing a crime at a certain time. Additionally, many crimes are not impacted by sentence enhancements. Serious crimes such as rape and murder, are most frequently one-time offenses and as such are deterred with less frequency than other serious offenses included in the legislation. Thompson also points to the fact that the law's enforcement within California counties varies and, in most cases, areas in which the law is enforced less strictly had larger drops in crime than their less liberal counterparts (Thompson 2002).

Worrall (2004) attempted to incorporate the best practices of previous studies while correcting for errors in other researchers' modeling. The study models the incapacitative effect of three-strikes along with its deterrent effect. Following Shepherd (2002) this study uses the probability of receiving three-strikes to study the deterrent effect. To model incapacitation the study follows Marvell and Moody (2001), who used a linear trend variable starting in the year of passage of the law through the last year in their dataset; with a negative and significant coefficient indicating incapacitation. After controlling for county-specific factors and economic and demographic factors the study concludes that the deterrent and incapacitative effects of the three-strikes legislation is weak, at best. The results can be drawn into question, as it is rather unclear how the trend variable actually measures the incapacitation effect. The negative coefficient of the trend variable is more likely to pick up the negative trends in crime following three-strikes.

While the attempt to differentiate between deterrence and incapacitation in Worrall's (2004) study is a significant one, we believe that the measure of incapacitation is inadequate. In the present study we try to provide a more definitive measure of incapacitation by tracking the change in prison population. As Kessler and Levitt(1999) 
point out, "(i)f incapacitation is the primary force, then three-strikes laws will lead to enormous increases in the numbers of prisoners ... that is largely aged out of crime." In contrast "if deterrence is the operative force, then three-strikes laws will lead to an equilibrium with both lower crime and lower levels of incarceration..." Following, this argument we use the change in prison population as our variable to test for incapacitation. The initial goal of this legislation was to reduce crime by raising its costs. Thus if incapacitation is the force behind the decline in crime in California, the variable should have a negative and significant coefficient i.e. as more criminals are put behind bars less crime is committed. However, if the coefficient is positive, as Kessler and Levitt posit, deterrence must be at work. Seeing a prison population decline in spite of persistence in strike convictions is an indicator that the public at large is being deterred from a life of crime.

Further, to test if sentence enhancements under the three-strikes legislation is what causes this deterrent effect, we use the probability of receiving three-strikes ${ }^{3}$ measured by dividing three-strikes sentences by the number incarcerated for all crimes.

\section{MODEL AND VARIABLES}

This study uses time-series data on total, violent and property crime for the period 1984 through 2004, to measure the deterrent and incapacitative effects of the three-strikes legislation in the state of California. In addition to controlling for socio-economic factors, the study also controls for law-enforcement variables and handgun sales. The study models the incapacitation effect using data on the change in prison population, instead of a trend variable used in previous studies, while and the deterrence effect is measured by the probability of third-strike convictions.

$$
\begin{aligned}
& \text { Crime }_{t}(i)=\beta_{0}+\beta_{1} \text { police }_{t}+\beta_{2} \text { prosecutors }_{t}+\beta_{3} \text { handguns }_{t}+\beta_{4} \text { income }_{t} \\
& +\beta_{5} \text { ethnicity }+\beta_{6} \text { 3Strikes }_{t}+\beta_{7}(\Delta \text { prison pop })_{t}+\varepsilon_{t} \quad \text { (Eqn 1) }
\end{aligned}
$$

Police- the number of police employed by the state and prosecutors - the number of prosecutors in the state measure the effects of law enforcement. An increase in the number of police can mean that more arrests are made and more crimes are stopped during their commission. The number of prosecutors dictates how many cases go to trial; if more cases are pursued to their full extent and longer sentences are given, people, in theory, may be less likely to commit crimes, especially when taking three-strikes into account.

Handguns - the number of handguns sold goes a long way to explain how many crimes, especially violent, are committed. The available data, however, comes from new arms dealer sales figures. There are far more guns on the streets which are unaccounted for and compiling even reasonably accurate figures to demonstrate this is difficult. Additionally, new gun sales number could reflect citizens acquiring guns to defend against violent criminals (though this is unlikely, considering crime rates are declining), which would undoubtedly skew the results. Still, the use of a firearm in the commission of any crime can make it a felony case, and so this number cannot be ignored when developing a model. To account for the effects of socio-economic factors our model controls for income - measured by median household income and racelethnicity - percentage of black and hispanic population.

Finally, we use the probability of 3Strike to measure the deterrent effect of extended sentences under the three-strikes legislation. Probability of 3Strike is measured by dividing the number of three-strikes sentences by the number incarcerated rather than number of arrests used by Worrall (2004). Using the number incarcerated in the denominator is more appropriate, as every arrest does not necessarily result in conviction. Shepherd (2002) has argued that including information on the frequency of three strikes, accounts for how "aggressively" the three-strikes legislation is prosecuted, which is superior to using a simple 0-1 dummy variable (e.g. Marvell and Moody, 2001). Further, we believe that the effect of sentence enhancement is best studied using three-strikes sentences. Threestrikes sentences, rather than two-strikes, should have a stronger deterrent effect on would-be criminals as the length of sentencing is significantly enhanced for a third-strike (25 years to life).

\footnotetext{
${ }^{3}$ We believe that using three-strikes conviction instead of two- and three-strikes is a better and clearer measure of the deterrent effects of extended sentences, as the average length of a three-strike conviction is 37.5 years while that of a two-strike is only around 3.9 years (Shepherd, 2002).
} 
Change in prison population - is the variable used to test if incapacitation is the driving force behind the decline in California crime. While a negative and significant coefficient supports incapacitation, a significant positive coefficient supports deterrence (see discussion in the previous section). Kessler and Levitt (1999) wrote that the distinction between the two forces of deterrence and incapacitation is not merely an academic exercise; rather it is crucial to determining the costs and benefits associated with sentence enhancements, particularly for three-strikes laws.

Most of our data on crime rates, law enforcement, handguns, and demographics were obtained from the Criminal Justice Statistics Center, State of California, Department of Justice ${ }^{4}$. Median household income is obtained from the Department of Commerce, Bureau of Economic Analysis.Three-strikes sentences and change in prison population figures were taken from the California Attorney General's Office 10 Year report on three-strikes laws. ${ }^{5}$

\section{RESULTS}

The model outlined above is estimated separately for violent, property and total crime with data for the period 1984 through 2004. The results are reported in table 1.

Table 1: Regression Results

\begin{tabular}{|c|c|c|c|}
\hline & Total Crime & Violent & Property \\
\hline Intercept & $\begin{array}{l}3262.374 \\
(3.50)^{* * *}\end{array}$ & $\begin{array}{l}128.064 \\
(0.37)\end{array}$ & $\begin{array}{l}3134.086 \\
(5.17)^{* * *}\end{array}$ \\
\hline Police & $\begin{array}{l}0.010 \\
(0.57)\end{array}$ & $\begin{array}{l}0.004 \\
(0.66)\end{array}$ & $\begin{array}{l}0.006 \\
(0.51)\end{array}$ \\
\hline Prosecutors & $\begin{array}{l}0.017 \\
(0.44)\end{array}$ & $\begin{array}{l}0.014 \\
(1.02)\end{array}$ & $\begin{array}{l}0.002 \\
(0.10)\end{array}$ \\
\hline Guns & $\begin{array}{l}0.002 \\
(1.36)\end{array}$ & $\begin{array}{l}0.001 \\
(2.16)^{* *}\end{array}$ & $\begin{array}{l}0.001 \\
(0.86)\end{array}$ \\
\hline Median Household Income & $\begin{array}{l}-0.042 \\
(-1.42)\end{array}$ & $\begin{array}{l}-0.006 \\
(-0.55)\end{array}$ & $\begin{array}{l}-0.036 \\
(-1.87)^{*}\end{array}$ \\
\hline Black \& Hispanic Pop & $\begin{array}{l}119.934 \\
(2.63)^{* *}\end{array}$ & $\begin{array}{l}22.562 \\
(1.33)\end{array}$ & $\begin{array}{l}98.376 \\
(3.32)^{* * *}\end{array}$ \\
\hline$\Delta$ in Prison Pop & $\begin{array}{l}0.074 \\
(3.06)^{* * *}\end{array}$ & $\begin{array}{l}0.025 \\
(2.74)^{* *}\end{array}$ & $\begin{array}{l}0.049 \\
(3.14)^{* * *}\end{array}$ \\
\hline Three-Strikes & $\begin{array}{l}-115.729 \\
(-2.51)^{* *}\end{array}$ & $\begin{array}{l}-21.473 \\
(-1.25)\end{array}$ & $\begin{array}{l}-94.261 \\
(-3.15)^{* * *}\end{array}$ \\
\hline Adjusted $\mathbf{R}^{2}$ & 0.969 & 0.965 & 0.979 \\
\hline
\end{tabular}

* Indicates statistical significance at 0.10 level;**Indicates statistical significance at .05 level; *** Indicates statistical significance at 0.01 level

The numbers of police, prosecutors and handguns on the streets all had very small, seemingly negligible coefficients. An analysis of the t-stat values reveals that, for the most part, that they are statistically insignificant. In no model does the number of police play a significant role in reducing crime rates. The number of prosecutors also plays no role in deterrence. This is surprising; as the number of police and prosecutors employed by the state increase, the likelihood of being apprehended, prosecuted and convicted for committing a crime increases as well.

\footnotetext{
${ }^{4}$ Criminal Justice Statistics Center,http://ag.ca.gov/cjsc/datatabs.htm.

5 According to the report this data is obtained from the California Department of Corrections: www.corr.ca.gov/OffenderInfoServices/Reports/Annual/HIST2/HIST2d2002.pdf; www.corr.ca.gov/offenderinfoservices/reports/quarterly/Strike1/STRIKE1d0403.pdf.
} 
Instead of seeing the expected negative relationships, we see negligible, positive relationships, suggesting possibly that as crime falls, the number of law enforcement employees drops subtly as a result. The number of handguns sold on the year shows a positive and statistically significant relationship for violent crimes but not for property crimes or total crimes. This suggests that crime control variables together cannot explain the decline in crime rate in California.

It may be argued that an improvement in economic well-being should have a negative impact on crime. While the coefficient for median household income has the correct sign in all three cases it turns out to be insignificant in explaining total and violent crime. Median household income is close to significance when evaluating property crimes alone, suggesting that socioeconomic factors do, in fact, play a role in deterring crimes committed for financial benefit. Violent crimes are more difficult to predict, especially since a large proportion of it is the result of gang violence.

Because the population size of both African-American and Latino street gangs in California is unavailable, to compensate, the total minority populations were evaluated instead. Being as Asians are historically the victims of violence, they were left out of the equation. California's most active violent gangs all have primarily AfricanAmerican or Latino membership; furthermore, those most impacted by economic difficulties and social proximity to criminal circumstances are the same two populations of individuals. The high coefficients and strong t-statistics suggest that African-American and Latino populations do have strong impacts on crime rates.

Turning to our measure of incapacitation - the coefficient for change in prison population is surprisingly positive and statistically significant in all cases. As indicated in an earlier discussion - for incapacitation to be the driving force behind falling crime rate in California this coefficient should be significantly negative. This relationship is so strongly positive, in fact, that we can confidently state that the results indicate that there is virtually no measurable incapacitation effect on crime rates, at least when analyzing current data. Instead the positive and significant relationship suggests that both factors being analyzed move in the same direction. As crime goes down, so does the additions to prison population - which Kessler and Levitt (1999) indicate is consistent with deterrence! ${ }^{6}$

Can the deterrent effect be attributed to the three-strikes legislation? The significance of the three-strikes law in deterring crime is notable in these regression analyses. The coefficient of the three strikes variable is large and negative for total and violent crime rate regressions. Our results suggest that the existence of the three-strikes law deters the commission of roughly 116 total crimes per 100,000 citizens of California each year and about 94 property crimes. The aforementioned Kessler and Levitt (1999) article supports our findings. Furthermore, because of how we separated out the incapacitation effect, we can state that it is the three-strikes legislation that is largely responsible for this drop in crime rates.

The negative coefficient on the strike sentence variable is insignificant and much smaller in magnitude for violent crime (which includes: homicides, rape, robbery and assault). These findings support the results from Shepherd (2002) and Thompson (2002) and confirm the prediction that stricter sentencing may not lead to significant decreases in the number of murders and rape committed. Finally, the adjusted $\mathrm{R}^{2}$ in all three regressions is around $97 \%$ which indicates a good fit.

We should however point out that the lack of evidence for incapacitation effect in our study is based on a limited time-series following the passage of the three-strikes legislation. Many offenders who have received enhanced sentences are still serving standard jail terms after the law's passage; it is not until they begin serving their enhanced terms that a tangible incapacitation effect on crime could be measured. Finally, the number of illegal immigrants in California, the membership size and activity of gangs in many areas and figures related to education were not readily available for analysis..

\footnotetext{
${ }^{6}$ In this regard Worrall's (2004) interpretation of the negative coefficient of the time-trend variable as a measure of incapacitation may be questioned. It is more likely that the negative time-trend picks up the negative trend in crime in California.
} 


\section{CONCLUSION}

The results of the regression analysis show that California's three-strikes law is statistically significant as a factor that drives down the rate of crime; it plays a much greater role in deterrence when economic factors are controlled for even when those factors prove to be not significant themselves. Surprisingly, the number of police, number of prosecutors employed by district attorneys and the number of handguns sold in a year are not significant in driving crime down.

In this study we devised a measure of incapacitation that tracks the change in prison population against crime. The concurrent declines in prison population and all three measures of crime, refutes the argument that incapacitation might have led to the recent declines in crime rate in California. Instead, the positive relationship between the two variables supports deterrence. It appears that the three-strikes legislation deterred would-be criminals from committing new crimes thereby reducing the crime rate and the additions made to the prison population.

The fact that the model for violent crime behaves differently than total and property crime, especially that the three-strikes legislation has no statistical significance in its deterrence suggests that on the whole, violent crime is generally harder to prevent than other types of crime. The length of sentencing for murder and rape are significantly high to start with, which might also make the three-strikes law less effective in deterring such crime.

While there are suggestions as to how to tweak the law to keep certain offenders from serving disproportionately long sentences for seemingly minor crimes, for the most part, one can argue that sentencing enhancements can act as an effective deterrent to crime. While the three-strikes law is not the only answer, it is part of a whole that has provided a solution to what was fast becoming a serious problem in the state of California. The legislation has been deemed so successful, in fact, that almost all states in the union have adopted their own version of a three-strikes law; the federal government has done so as well.

Finally, a future avenue for research on this issue would be to see the impact of the three-strikes law on the behavior of repeat offenders. The nature of the three strikes law is such that, repeat offenders bear the immediate brunt of the legislation. It would be interesting to see if the harsh sentencing standards for second and third strike eligible offenders alters the likelihood and the nature of crimes committed!

\section{AUTHOR INFORMATION}

Anusua Datta, Ph.D., Associate Professor of Economics, School of Business Administration, Philadelphia University. Dr. Datta received her Ph.D. in Economics from University of Wisconsin, Milwaukee in 1999. Her fields of research include International Economics and Growth, Industrial Organization and Health Policy. She has expertise in econometric modeling. She has presented her research at various national and international conferences and has published in refereed journals like the Southern Economics Journal, Economics Letters, Applied Economics, Journal of International Economics, Atlantic Economic Journal, and Review of International Economics. http://faculty.philau.edu/Dattaa

John Kelly, BS Business Management, School of Business Administration, Philadelphia University. He grew up in suburban Philadelphia, attending Malvern Preparatory School and then matriculating to Philadelphia University to take advantage of the professional education and close faculty interaction. He graduates in May 2009 with a BS in Business Management. He has presented his research at several undergraduate conferences. John currently works in Sales and Business Development and plans to acquire a dual M.B.A./J.D.

\section{REFERENCES}

1. Becker, G.S. (1968). Crime and Punishment: An Economic Approach. Journal of Political Economy. 101(3), 385-409. 
2. Brown, Brian and Jolivette, Greg. (2005). A Primer: Three-strikes - The Impact After More Than A Decade. Retrieved 2 December 2007. Website:

http://www.lao.ca.gov/2005/3 Strikes/3 strikes 102005.htm

3. Kessler, Daniel and Levitt, Steven D. (1999). Using Sentence Enhancements to Distinguish between Deterrence and Incapacitation. Journal of Law and Economics. 42(1). 343-363.

4. Macallair, Daniel and Males, Mike. (1999). Striking Out: The Failure of California's “Three-strikes and You're Out” Law. Retrieved 15 December 2007. California's Center of Juvenile and Criminal Justice.Website: http://www.cjcj.org/pubs/three_strikes/strikingout.html

5. Marvell, T. B., and Moody, C. E. (2001). The Lethal Effects of Three-Strikes Laws. Journal of Legal Studies, 30, 89- 106.

6. Shepherd, Joanna M. (2002). Fear of the First Strike: The Full Deterrent Effect of California's Two- and Three-Strikes Legislation. The Journal of Legal Studies, 31(1), Part 1. 159-201.

7. Helland, Eric and Alexander, Tabarrok, (2002). Does Three-strikes Deter? A Non-Parametric Estimation. Journal of Human Resources 42(2). 309-330

8. Thompson, Christi. (2002). The Impact of Three-strikes: A Socio-Legal Perspective. Law and Society Review at UCSB, Vol 1, 2002.

9. Worrall, John. (2004). The Effect of Three-strikes Legislation on Serious Crime in California. Journal of Criminal Justice 34. 283-296.

10. Zimmring, F.E., Kamin, S. and Hawkins, G. (1999). Crime and punishment in California: The impact of three-strikes and you're out. Berkeley, CA: Institute of Governmental Studies Press. 